\title{
TRAINING OF COMPUTER CONTROL BY USING GAME EEG HEADSET IN PATIENTS WITH PARALYSIS OF LIMBS
}

\section{Jan JÁRA}

\begin{abstract}
The article describes the experience of using gaming headset Epoc EEG Headset for practicing control of the computer through mind with patients with limited or no ability to control limbs. This was done in partnership with patients Rehabilitation institute in Kladruby. Describes a method patients' motivation, work progress and results achieved. In the first case study describes a young man who was capable of minimal movement of the head. With G-sensor with high gain could move almost across the screen with the mouse cursor, and using a limited ability to control the facial expression muscles to control mouse buttons. In the second case study describes a patient pre retirement age with limited ability to speak and unilateral paralysis of the limbs. With the motivation and deploy the proposed procedure discovered in himself the ability paralyzed leg after all to control.
\end{abstract}

Key words: EEG, Epoc headset, mobility aids, rehabilitation, training, casuistry, motivation, mental mapping control of limbs

\section{NÁCVIK OVLÁDÁNÍ POČÍTAČE POMOCÍ HERNÍ EEG ČELENKY U PACIENTƯ S OCHRNUTÍM KONČETIN}

Resumé: Článek popisuje zkušenosti s využitím herní EEG čelenky Epoc Headset při nácviku ovládání počítače myslí u pacientů s omezenou či nulovou schopností ovládání končetin. To probíhalo ve spolupráci s pacienty Rehabilitačního ústavu v Kladrubech. Popisuje způsob motivace pacientů, postup práce a dosažené výsledky. V první kazuistice popisuje mladíka, který byl schopný pouze minimálního pohybu hlavou. Pomocí G-senzoru s vysokým zesílením dokázal pohybovat téměř po celé obrazovce s kurzorem myši, a s využitím omezené schopnosti ovládání mimických svalů ovládat tlačítka myši. $\mathrm{V}$ druhé kazuistice popisuje pacienta předdůchodového věku s omezenou schopností mluvení a jednostranným ochrnutím končetin. Díky motivaci a nasazení navrženého postupu objevil v sobě schopnost ochrnutou nohu přece jenom ovládat.

Klíčová slova: EEG, Epoc headset, kompenzační pomůcka, rehabilitace, nácvik, kazuistika, motivace, mentální mapování ovládání údů

\section{1 Úvod}

Epoc Headset je zařízení na ovládání her pomocí EEG signálu. To nemusí sloužit pouze k zábavě zdravých lidí, ale i může pomoci lidem s různým druhem postižení. Dostupnost tohoto zařízení oproti profesionálním EEG čepicím s př́islušným HW je několika řádově vyšší, a př́prava na vlastní seanci také. Proto se ve světě snaží toto zařízení využít pro práci pacienty s poškozenými nervovými drahami. [1]. Využití těchto možností bylo testováno $\mathrm{v}$ Rehabilitačním ústavu $\mathrm{v}$ Kladrubech $\mathrm{v}$ roce 2011 u 11 vytipovaných pacientů. Nácvik probíhal u osob s částečným či úplným ochrnutím horních i dolních končetin. Cílem testování bylo ověřit možnosti použití tohoto zařízení jako dostupnou kompenzační, či dokonce rehabilitační pomůcku.
Dodaný SW ve spolupráci s HW dokáže ovládat počítač několika zpưsoby:

\subsection{Gyroskop}

Gyroskop pochopitelně nemá se snímáním EEG nic společného. Převádí pohyb hlavy na kurzor myši. Obdobnou funkci by zvládl i chytrý mobilní telefon připevněný na čepici posazené na hlavě. Vhodným zesílením se dá dosáhnout pohyb po obrazovce i nepatrným pohybem hlavy $\pm 0,5 \mathrm{~cm}$. Př́ tomto zesílení se však ukázalo, že je velmi obtížné zacílit kurzorem požadovaný objekt díky nepřesnosti způsobené velkým zesílením. Gyroskop na podnět - pohyb hlavy reaguje okamžitě. Tento způsob ovládání byl vždy použit pro pohyb kurzoru na obrazovce. 


\subsection{Ovládání mimických svalů}

V základu lze detekovat následující pohyby mimických svalů:

- pohled vlevo/vpravo

- mrknutí

- mrknutí vlevo

- mrknutí vpravo

- zvednutí obočí

- vycenění zubů

- úsměv

$\mathrm{Na}$ tento pohyb je možné namapovat nějakou událost. $\mathrm{V}$ našem př́padě se jako jednoznačný a nesamovolný podnět ukázal stisk zubů. Na druhém místě pak úsměv či povytažení obočí. Mrknutí, mrknutí každým okem zvlášt se ukázalo jako obtížně proveditelné. Pohled vlevo či vpravo nemusí být vždy záměrný. Od záměru provést nějaký mimický povel k odezvě na počítači je sice minimální zpoždění, ale nijak neruší ovládání. Problém se ukazuje spíš s nutností individuální kalibrace, která může trvat od minut až po desítky, a pacient na ní nemusí mít vždy trpělivost. Navíc tato operace vyžaduje, při neschopnosti pohybu rukou, asistenci druhé osoby. Obě osoby musí nastavování rozumět, a hledat vhodný kompromis. Což tedy klade zvýšené nároky na asistenční osobu. Mimickému podnětu je možné přiřadit klávesu, či tlačítko myši. V podrobnějším nastavení se nastavuje i práh citlivosti a časování. Tím se však z původně spojité veličiny $\mathrm{v}$ rozsahu $0-1$ stává pomocí prahování vlastně neproporcionální regulace. Pokud by se tedy použil jiný interface, šlo by tedy mírou úsměvu či zvednutí obočí posunovat myš po obrazovce. Tato varianta zatím nebyla testována. Při ovládání někdy počítač "pálí" samovolně, někdy naopak nereaguje na skutečný podnět. Vyhodnocování ochromí silné mimické gesto, které saturuje ostatní funkce - např́iklad svraštění čela.

\subsection{Ovládání myšlenkou}

Ovládání počítače př́mo myšlenkami je nejobtižnější disciplína. Nácvik s dodaným SW probíhá pomocí levitující kostky. Uživatel si má představit, že levitující kostka se pohybuje nahoru, dolu, doleva, doprava, dozadu, dopředu, otáčí se, mizí, atp. Na tyto podněty lze pak obdobně jako na podněty $\mathrm{z}$ mimických svalů navázat stisk kláves, či $\mathrm{v}$ přiložených aplikacích, např́íklad listování albem fotek.

Kalibrace na rozdíl od podnětů z mimických svalů je daleko obtížnější. Neexistují pro dané podněty nahoru, dolu, doleva doprava, atp. žádné posuvníky určující míru. Pro každý podnět je potřeba vytvořit několik šestisekundových záznamů. Ty jsou jako trénovací vzorky zpracovány a uloženy, pro pozdější porovnání v ostrém provozu. Nejprve je potřeba udělat alespoň jeden vzorek, kdy člověk nemyslí vůbec na nic. Už to samotné je pro někoho obtížná disciplína... Trénovací aplikace levitující kostka nabízí současné uplatnění 4 podnětů $\mathrm{z} 13$. Nejjednodušší je naučit se ovládat současně jeden. Dva je obtížné, ale dá se zvládnout natrénovat do čtvrt hodiny s úspěšností podle [1] 46,83\%. Nejlepší účastník měl scóre $75 \%$ a nejhorší $25 \%$. Zvládnout natrénovat tři povely najednou vyžaduje značné úsilí a neustálé přetrénování aplikace Cognitiv Suite. Na nacvičování čtyř povelů současně neměl zatím nikdo trpělivost. Pokud se na nacvičování podíváme pohledem výuky hry na hudební nástroj, pak je jasné, že za jeden den či za čtvrt hodiny se na housle také nikdo hrát nenaučí. Z pohledu regulační techniky toto ovládání pomocí myšlenek má velké dopravní zpoždění Td. Od záměru provést nějaký povel $\mathrm{k}$ jeho provedení na obrazovce uplyne doba přibližně od $500 \mathrm{~ms}$ do $10 \mathrm{~s}$, a to s opakovaným vysíláním podnětu do doby než se akce povede. Ruku na srdce: Hru „neprováděli houslisti“, ale lidé, kteří párkrát drželi housle v ruce. Předpokládám, že pravidelným cvičením s EEG čelenkou s úsilím

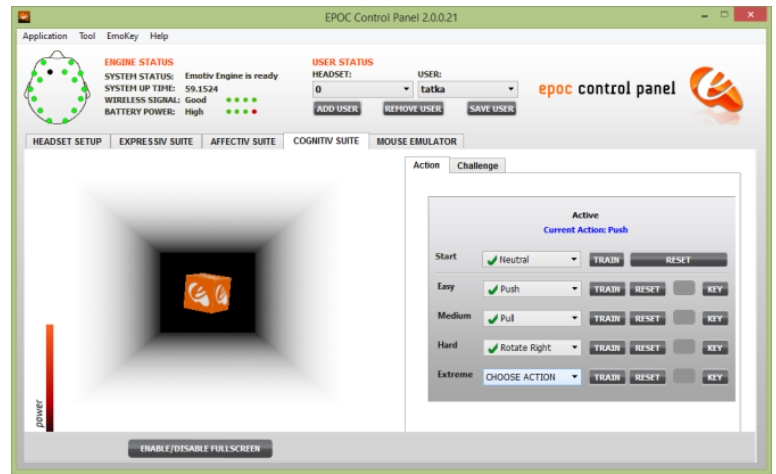

jako se cvičí na housle, by se výsledky dostavily. Obr 1: GUI pro trénováni ovládáni myšlenkami.

Zdálo by se, že pro účely ovládání počítače či rehabilitace, je tato možnost $\mathrm{k}$ ničemu, ale přesto se našlo pro i pro tento způsob využití.

Člověk obvykle snahu na ovládání údu, který nevykazuje žádnou reakci, vzdá. Část populace umí stříhat ušima či roztahovat chřípí. Pokud to čtenár neumí, necht' si to zkusí natrénovat. Zřejmě se dostane do podobného pocitu jako ti, co se snaží pohybovat ochrnutou končetinou. 
Autorem objevená metoda by se dala nazvat Mentálním mapováním ovládání údů a využívá princip augmentované reality. Počáteční mentální úsilí pohnout např́klad ochrnutou nohou, se namapuje jako pohyb levitující kostkou. Po jisté době, kdy už pacient by podléhal skepsi, že mu to $\mathrm{s}$ tou nohou nejde, levitující kostka presto odskakuje. Toho nelze docílit jinak, než původní snahou o pohyb končetiny. Pacient tedy vidí reakci, když ne na noze, tak alespoň na počítači. To samozřejmě podpoří jeho další úsilí.

\subsection{Monitoring duševního stavu}

Počítač snímá nezávisle tři duševní stavy: vzrušení/zklidnění, zaujmutí/nezájem a meditace. Jejich hodnoty kalibruje a zobrazuje ve dvou grafech v krátkém a delším časovém průběhu. V dodávané hře ovlivňuje snímání duševního stavu barevnost pozadí.

\section{Kvadruplegický pacient}

Student prrijatý na pedagogickou fakultu dostal ve svých 21 letech klíštovou encefalitidu. Ta byla tak silná, že byl uveden do umělého spánku. Z něho se po 3 měsících nemohl probudit. Po probuzení byl kompletně ochrnutý a v rehabilitačním ústavu se učil polykat, mluvit a hýbat mimickými svaly. V podstatě se jeho stav blížil tzv. syndromu uzamčení. $\mathrm{O}$ práci s takovýmito pacienty s využitím EEG pojednává [7].

Zdravotnickým personálem byl posazen do polosedu, byla mu nastavena čelenka a prristaven notebook do jeho zorného pole. Pomocí zařízení Epoc headset se pokoušel pohybovat kurzorem myši. To šlo obtížně, protože hlavou dokázal pohnout cca. $\pm 0.5 \mathrm{~cm}$ Přesto při maximálním zesílení dokázal přejet 3/4 prostoru obrazovky. Př́i takto velkém zesílení je pochopitelně obtížné se do něčeho trefit, ale postupně se to naučil. Tím jak se zařízením dlouhodoběji pracoval, byl schopen více pohybovat hlavou. Mohlo být proto sníženo zesílení, a tím se lépe dařilo zacilovat. Přestože měl částečně ochrnuté i mimické svalstvo (prováděl rehabilitaci) ovládat počítač pomocí mimického svalstva se mu dařilo. Dokonce lépe než některým zdravým lidem, a to i přes to, že jeho pohyb mimických svalů byl $\mathrm{v}$ některých př́padech sotva znatelný. Stiskem zubů ovládal levé tlačítko myši a úsměvem pravé. Psaní na virtuální klávesnici bylo pro něj velice obtížné, jedno slovo o 5 písmenech napsal s opravením překlepů cca za minutu a půl. Přesto byl rád, že si mohl bez cizí dopomoci pracovat na internetu. Práce se zařízením ho unavovala pro obtížnost dlouhodobě sedět $\mathrm{v}$ polosedu. Jeho elán a chut' pracovat se zařízením vytvářela dobré výsledky i $\mathrm{v}$ ostatních typech ovládání tohoto zařízení. Přesto, jakmile se mu začala po několika měsících probouzet $\mathrm{k}$ pohybu ruka, napjal veškeré úsilí k ovládání počítače rukou.

Lze se domnívat, že mimovolným procvičováním při ovládání počítače, se mu podařilo zrehabilitovat více pohyb hlavou, a ovládání mimických svalů. Nelze pochopitelně pominout zásluhu odborné péče rehabilitačního ústavu. A také možná dalšího provedeného experimentu.

Jelikož pacient byl dříve trumpetista a autor tohoto článku je také, byl proveden následující experiment. Byla mu nabídnuta asistovaná hra na trubku. $\mathrm{Na}$ to se však rodiče dívali skepticky, protože po tracheostomii nedokázal vyvinout tlak a sešpulit rty. Díky autorově zkušenosti se žest'ovými nástroji přinesl na př́ští schůzku nejen trubku, ale i baskř́ílovku a heligón at' se vyzkouš́, co by pacient zvládl. Trubka (má malý nátrubek - cca $2,5 \mathrm{~cm}$, je potřeba vysoký tlak - asi jako na nafouknutí balónku) - pacient nedokázal vyloudit žádný tón. Baskř́́dlovka (nátrubek o průměru cca $4 \mathrm{~cm}$, tlak střední - asi jako když chcete odfouknout piškot ze stolu) - podařilo se několik tónů. Heligón - pochodová verze tuby (nátrubek o průměru cca $6 \mathrm{~cm}$, nízký tlak, ale náročné na množství vzduchu - asi jako když chcete odfouknout míček) - tón se nepodařil. Jednak pro potřebné velké množství vzduchu, a jednak protože rty $\mathrm{v}$ nátrubku nebyly schopny vytvořit charakteristické bzučení. Baskřídlovka měla úspěch.

Byla vidět radost $\mathrm{v}$ očích pacienta, že dokázal vyloudit zvuk. On, který dokázal vytvořit svým hlasem jen tiché zvuky. Vytvořil zvuky, které byly slyšet přes zavřené dveře až na chodbu. $\mathrm{Z}$ počátku zvládnul jen pár tónů a unavil se. Bylo to náročné jak na plíce, tak na rty a na svaly na krku. Rodiče, sourozenci i př́telkyně však pravidelně baskř́ílovku přikládali, a dokonce se naučili ovládat i klapky a míru př́tlaku na rty. Díky hře na baskř́ílovku, posiloval tedy plíce, rty, krk ale i sebevědomí, že něco dokáže. Baskř́dlovka sice s didaktikou ICT nesouvisí, ale dokresluje pokus o vícestrannou péči o pacienta a tím bohužel nejednoznačné závěry, která metoda jakou měrou pomohla $\mathrm{k}$ rehabilitaci mimických svalů pacienta. 


\section{Hemiplegický pacient}

Přibližně šedesátiletý starosta obce se v Rehabilitačním ústavu v Kladrubech zotavoval z mozkové př́íhody. Ochrnutý byl na pravou polovinu těla, včetně obličeje a neartikulovaně mluvil. Vážně pronesenému vtipu s běžnou větnou melodií a výrazem v obličeji se ale smál. Tímto jednoduchým testem si autor tohoto článku ověřil, že pacient má dostatečné rozumové schopnosti $\mathrm{k}$ pochopení toho, co se po něm bude chtít. Přestože, měl zkušenosti s ovládáním počítače spíš malé, a počítač by mohl ovládat levou rukou, byl zahrnut do testování. (Mladí pacienti se zkušenostmi s počítačem, s možností ovládat počítač pravou rukou to vzdali po prvním sezení.) Pacient byl však trpělivý a se zájmem spolupracoval. Jednotlivé testované disciplíny zvládal obtížněji, postup mu musel být několikrát vysvětlován. Nakonec se naučil myslí obstojně ovládat i levitující kostku.

Motivace a vhodné navození atmosféry je velice důležité. $\mathrm{V}$ následujícím odstavci se autor článku pokusí rekonstruovat a okomentovat rozhovor jak přibližně proběhl mezi ním a pacientem. Rozhovor byl veden v klidu, rozvláčně, byl př́tomen asistent (bakalant) zajišt'ující technickou připravenost a zápis. Pacient seděl na vozíku.

\section{A: „Dobrý den pane Kozelko!“”}

B: Neartikulovaný pozdrav.

A: „Dneska je venku nádherně, houbařská sezóna vrcholi." Př́sun $\mathrm{k}$ oknu s pacientem, kochání se výhledem.

A: „Taky houbařite?"

$\mathrm{B}:$,Ne.“

A: „Jsou lidi, který když jdou do po lese, si s gustem kopnou do prašivek". Př̀ těch slovech $\mathrm{v}$ zorném poli pacienta si s radostí si kopnout.

A: „... takhle krásně si do ní kopnout." Postavit si PET láhev $\mathrm{s}$ vodou a při slovech kopnout do ní mírně kopnout až se odkutálí.

A: „Chcete to zkusit, - s tou vaši nohou?" jakoby mimoděk proneseno.

B: „Ale já s ní přece nepohnu.“ - těžce pronesená neartikulovaná odpověd'

A: „To nevadi, ale můžeme to zkusit s pomoci tý čelenky?"“

B: „Ano, ano.“ Nadšená odpověd'.

A: „Udéláme takový pokus: Pan Šram Vám nasadí na hlavu čelenku a pripraví počítač. A Vy až budete chtit kopnout do prašivky, nastavíme to tak, aby v počitači odletěla kostka.“
B: „Ano, ano.“ Než bude vše po technické stránce prípraveno - cca 2-3 minuty. Udržovat s pacientem oční kontakt, něco mu vyprávět, říct nějaký vtip, kterému se určitě zasměje. (je těžké odhadnout)

A: Významně se rozhlídnout po místnost: „Tak houbu tady nemáme tak použijeme tu flašku. Já ji podržím takhle dvěma prsty za vičko, a dám Vám jí před zdravou nohu a Vy mi jí vykopnete."

B: pacient se zdráhá.

A: „No jen se nežinýrujte, aspoň uvidite doktora z univerzity, jak po pacientech uklizi povalujicí se flašky!" - to ho rozesmálo.

B: několikrát si s gustem kopnul, a bylo vidět, jak ho to baví

A: „Tak a ted' to zkusime s tou druhou nohou." Asistent mezitím spustí nahrávání myšlenkových pochodů pro povel vzdálení se kostky. Někdy kopne pacient i tou zdravou. Takové nahrávky ruší. Využíváme pacientovo nadšení a zaujetí z předchozí hry.

B: Pacient zkouší kopat, ale nejde to. Nadšení postupně upadá.

B: ,Nejde to.“ - již poněkud zkroušeně

A: „To nevadí, ale podivejte - kostka odskakuje. A to, jak vite z dřivějška, neudèláte jinak, nežže se budete snažit na to myslet." Teprve ted' si pacient všímá, že se děje i něco na počítači. Ponechán si zápal a nadšení, viditelné emoce, aby pacientovi bylo žinantní zklamat nadšeného doktora $\mathrm{z}$ univerzity, který kvůli němu sbíral po zemi lahve.

B: „Kostka odskakuje, noha nic.“ - neartikulovaně naznačí pacient asi po 5 minutách experimentu

A: „Děláte to dobře, zkusime počitač dát tak, abyste viděl jak na kostku, tak na nohu a na tu flašku co před ní držim. "Úsměv na tváři, nadšení si stále ponechat.

B: Po několika snaženích se noha pohnula, sjela ze stupačky na vozíku. Flašku duchapř́itomně nenápadně pouštím.

A: „Skvělé, vykopnul jste mi flašku tou ochrnutou nohou." Emoce, emoce, emoce, radost, oční kontakt.

B: „To jsem netušil, že dokážu.“ Neartikulovaně a s radostí.

A: „Tak a ted” to musime rychle ještě nékolikrát zopakovat, abychom si to procvičili $k d y z ̌$ už to ted' umite. "

B: ,Ano, ano.“ nadšeně.

Po té, co to uměl pacient na požádání s počítačem, bylo přistoupeno na nácvik výkopu bez 
počítače. I to se dařilo. Pacient byl nadšený, autor článku s asistentem pochopitelně také. Promyšlená herecká motivační etuda se vyplatila.

Po čase jsem ho potkal na chodbě a promluvil $\mathrm{s}$ ním pár vět. Až $\mathrm{v}$ autě jsem si uvědomil, že mluvil už normálně. O biofeedbacku se hovoři jako o metodě, která pomáhá rehabilitovat poškozený mozek [2]. Snad i náš experiment s EEG čelenkou a biofeedbackem pomohl zmiňovanému pacientovi.

\section{Diskuze a závěry}

Naskýtá se otázka, jestli tento článek souvisí s didaktikou informatiky, či jestli provedený výzkum je pedagogický výzkum zaměřený na vzdělávací oblasti ICT. Domnívám se, že ano.

Práce nezkoumá EEG signály, ani rehabilitační postupy. Práce hledá postupy jak naučit postižené pacienty využívat ICT. Ukazuje se, že vlastnictví př́slušného ICT nedeterminuje úspěch, ale je potřeba hledat metody jak pacienty aktivizovat. Dále je potřeba hledat vhodné filtry, u koho zařízení nasadit. Zjištováním spolehlivosti čelenky emotiv Epoc podle vybraných scénářủ se zabývá [1].

Pro pilotní projekt testování byli vybíráni pacienti s paraplegií, hemiparézou, triplegií a kvadruplegií způsobené bud' poškozením páteře či mozku. Důležité bylo, aby měli předchozí zkušenosti s ovládáním počítače, dále pak dostatečné rozumové schopnosti $\mathrm{k}$ pochopení ovládání a využití počítače.

Závěrem je potřeba říci, že myš je myš. Pokud má pacient alespoň zbytkové schopnosti ovládat myš, jeho úsilí se napíná sem, byt' by ji, či trackball ovládal krkolomněji. Vynalézavost pacientů lze podpořit i výjevem, kdy pacient se ztrátou hybností prstů, měl mezi prsty propletenou vidličku a na konci vidličky - cigaretu. Pro pacienty tohoto typu se ukázal experiment ovládat počítač drobným pohybem hlavy a myšlenkou jako zajímavé zpestření pobytu $\mathrm{v}$ ústavu. V dalších lekcích pak neměli zájem pokračovat.

Získání pacientovi důvěry a motivace je velmi důležité pro dotažení experimentu do konce. Pacienti v Rehabilitačním ústavu $\mathrm{v}$ Kladrubech mají pracovní týden vyplněn procedurami téměř ve stejném časovém vytížení jako zdraví pracující. Př́ímý př́stup $\mathrm{k}$ nácviku nemusí být vždy nejlepší. Při slovech nácvik, rehabilitace, může vzniknout u pacienta psychický blok. Jak uvádí pan ředitel Ing. Josef Hendrych, MBA, pořádají v Rehabilitačním ústavu taneční večírek. Byt' jsou klienti s různými stupni postižení, snaží se zapojit do zábavy a ukázat se před ostatními. Dokážou při tom věci, které běžně nedokáží. Jejich pohyby za jejich běžnou hranici, při zábavě nejsou omezovány psychickým blokem typu. "Ted' jsem na rehabilitaci, a jestli se to nepodaří, co si počnu".

Při testování zařízení Epoc headset byla zvolena strategie, kdy pacient má spíš pocit, že prováděné testování je spíš zábava, experiment, než nějaký postup, který by mu měl pomoci. Osvědčilo se proto vymýšlet $\mathrm{k}$ nácviku a $\mathrm{k}$ motivaci různé legendy a hrát různé herecké etudy a do řeči vpašovávat průpovídky. Sběr a vymýšlení nových kousků rozšiřuje repertoár, ze kterého se pak dá vybírat u nového pacienta popř́ípadě u nových postupů.

Příklad osvědčených motivů, které byly rozehrány:

- Pacient: „Co to děláte?“ Asistent: „Vlhčím elektrody. Musím dávat pozor, abych si to nekápnul na šaty. To by mi do nich propálilo hned diru. “... Následuje zděšení a následně uvolnění.

- „Někdo se cpe, až se mu délají boule za ušima. A právě na ty boule je třeba umistit tuto referenční elektrodu. “...Pacient už si navždy pamatuje, kam elektrodu umístit.

- „Houbařská sezóna vrcholí. Jsou lidé, co chodí po lese a s gustem si kopnou do prašivky. Pojd'me si to zkusit kopnout s tou ochrnutou nohou." ...Neodolatelná touha po boření.

Testování $\mathrm{v}$ Rehabilitačním ústavu v Kladrubech ukázalo, že EPOC headset, tedy herní EEG čelenka může pomoci pacientům jako kompenzační, nebo rehabilitační pomůcka. V dalším výzkumu by bylo dobré hledat a rozvíjet didaktické metody, jak naučit pacienty s čelenkou pracovat a rehabilitovat. Dále pak vyvinout věrohodnější augmentovanou realitu, kdy průhledem skrz displej počítače a potažmo kameru, pacient $\mathrm{s}$ končetinou pohybuje, i když v reálu se to zatím nedaří. Př́íjemné na provedených výzkumech je to, že pomohly nejen výzkumníkovi, ale hlavně testovanému.

\section{Literatura}

[1] LANG, Matt. Investigating the Emotiv EPOC for cognitive control in limited training time. In: Investigating the Emotiv EPOC for cognitive control in limited training time [online]. UNIVERSITY OF CANTERBURY, 2012 [cit. 2013-11-19]. URL: <http://www.cosc.canterbury 
.ac.nz/research/reports/HonsReps/2012/hons_120 1.pdf $>$.

[2] NORDQVIST, Joseph. What is Biofeedback Therapy?. MNT [online]. 10.9.2013 [cit. 201311-19]. URL: <http://www.medicalnewstoday. com/articles/265802.php>.

[3] The Emotiv EPOC: Meeting the Future Head On. Smart Device Central [online]. [cit. 2013-1119]. Dostupné z: http://www.smartdevicecentral .com/slideshow/The+Emotiv+EPOC+Meeting+th e+Future+Head+On/248749_248750.aspx

[4] Modernizace infrastruktury RÚ Kladruby zvýšení kvality a efektivity léčebné rehabilitační péče. $<\mathrm{i}>$ Rehabilitační ústav Kladruby $</ \mathrm{i}>$ [online]. 2010 [cit. 2014-01-30]. Dostupné z: http://www.rehabilitace.cz/czech/index.php?page $=$ modernizace-infrastruktury

[5] SAM B. FOK, RAPHAEL SCHWARTZ, CHARLES D. HOLMES. ESE 498 - An EEGbased Brain Computer Interface for Rehabilitation and Restoration of Hand Control following Stroke Using Ipsilateral Cortical Physiology. In: [online]. [cit. 2014-02-09]. Dostupné z: http://ese.wustl.edu/ContentFiles/ Research/UndergraduateResearch/CompletedProj ects/WebPages/sp11/SamRaphaelChuck/Senior\% 20Design\%20Paper.pdf

[6] Emotiv Wiki [online]. 2014. vyd.

[cit. 2014-10-01]. Dostupné z: https://sites.google.com/a/emotiv.com/wiki/home
[7] HONIGSBAUM, Mark. Could this $\$ 300$ headset transform the lives of 'locked-in' patients?. Could this $\$ 300$ headset transform the lives of 'locked-in' patients? [online]. 2014 [cit. 2014-10-01]. Dostupné z: http://www.thegu ardian.com/technology/2014/jul/11/kickstarterheadset-locked-in-syndrome-communication [8] The Hong Kong Polytechnic University. (2013, May 15). Novel brain training device to reconnect brain and paralyzed limb after stroke. ScienceDaily. 2014 [cit. 2014-10-01]. Dostupné z: $\quad$ www.sciencedaily. com/releases/2013/05/130515124841.htm

[9] Radiological Society of North America. (2013, December 2). Novel rehabilitation device improves motor skills after stroke. ScienceDaily. 2014 [cit. 2014-10-01]. Dostupné z: www.sciencedaily.com/releases/2013/12/131202 082646.htm

Ing. Jan Jára, Ph.D.

Katedra informatiky

Jihočeská univerzita, Pedagogická fakulta, Jeronýmova 10, 37015 České Budějovice

Tel: 724258702

email: jara@pf.jcu.cz

WWW pracoviště: wvc.pf.jcu.cz 